\title{
POWER, KNOWLEDGE AND RESISTANCES IN THE STUDY OF SOCIAL MOVEMENTS
}

\author{
DEANNA DADUSC
}

SChool of Sociology, Social Policy and Social Research, University of Kent

\begin{abstract}
This paper will analyse the power relations involved in social movement research, exploring alternative epistemological practices that resist and subvert academic conventions in order to create new modes of knowing. I will critique the production of a knowledge that aims at liberation and emancipation by conducting research 'about' or 'on behalf of' social movements, and I will show how this approach might lead to their very subjection. It will be argued that, in order to avoid the reproduction of power relations they seek to resist, research practices need to go beyond dialectical modes of knowing, departing from assumptions of the subject/object of knowledge, of objective/subjective research and from the hierarchy between theory and praxis. A precedent is found in the research approaches of post-colonial, activist, and queer studies that seek to experiment different modes of knowing, based not on observation and participation, but on learning from the experience of resistance in social movements: in this way resistant practices become an epistemological perspective rather than an object of study, and research can become a tool of resistance.
\end{abstract}

\section{Keywords}

epistemology; resistance; squatting

\section{Corresponding author:}

Deanna Dadusc, Email: deannadadusc@gmail.com

Many thanks to the Amsterdam squatters' movement, to Hanneke Mol and Erika Doucette for letting me reflect on the strong entanglement between power and knowledge in academic research, and for introducing me to alternative modes of thought. 
W hen applying for government and university research grants, social researchers have to comply with a number of requirements. One the one hand academics are asked to pursue scientific research projects that will bring innovative theoretical insight to the discipline; on the other hand they are expected to produce results and practical advice for policy-makers. As the attention of founding committees revolves around the relevance of research projects for science and policy, academics often research and write with one eye on academia and the other one on governments, but there seem to be little awareness on how these requirements embody politics of truth that confine research practices to specific modes of knowledge. Without neglecting the importance of engaging in projects that are both theoretically and policy relevant, working exclusively from an academic or policy perspective and audience often entails dismissing the effects of power exercised by academic modes of knowing on the social field that is analysed.

Ethical committees are supposed to ensure that the field researched is not harmed through the research process. However harm is a vague concept, not ease to measure, evaluate and operationalise. Concerns for the population affected mainly revolve around the protection of anonymity and confidentiality of sensitive information. As in a museum, or zoo, researchers may watch, observe and ask questions, as long as no direct harm is inflicted on the object of study; however, the process that allows academics to place 'research objects' within an observational cage remains unquestioned.

Besides the specific methodological tools for social movements studies, both the role and perspective of the researcher in the struggles taking place are worth reflection. Although there is much reflection on how the researcher's standpoint and subjectivity influences the knowledge produced (Crampton \& Elden, 2007; Wray 2002), academics often lack reflection on the power exercised by their modes of knowledge and theoretical perspectives on the social movements researched. Most social movements scholars seem sympathetic with the movements they study, and aim to produce knowledge for emancipating and empowering groups struggling for social change. However it will be questioned to what extent these research practices that aim at producing social emancipation, still reproduce power relations that allow academics to exercise power on the reality analysed, thus resulting in the subjection, rather than the multiplication of practices of resistance.

As all modes of research have political consequences, and all forms of knowledge exercise power, a relevant question is how to transform these power relations through the very process of doing research? Or, in other words, how can research practices become tools of resistance not only for transforming society, but for subverting the very modes in which knowledge is produced and discursive formations become truth?

This paper will explore research practices that go beyond those traditional approaches that reproduce the scientific dialectic between object and subject of knowledge, and that aim at subverting the relations of power that place a hierarchy between theory and praxis, researchers and researched, and, in social movements studies, between academics and activists. This paper does not attempt to provide fixed answers nor solutions. Instead, it configures as an exploration in the field of epistemological practice, in order to problematise the power effects of different modes of knowing.

The starting point here is the research project through which these critical questions emerged; namely, the study of the criminalisation of squatting in the Netherlands. The resistant collectivities active in squatters movements aim to subvert the multiple modes of power that govern our societies, and the production of academic knowledge about movements is one such modes of power. Thus, when starting this research, it resulted important to explore possible epistemological practices that are not set up to produce scientific knowledge about squatting, but 
that, instead, are situated at the vantage point of the squatting experience, and are thus able to contribute in understanding and subverting the relations of power that movements are resisting. In other words, it has been necessary to implement research practices that, rather than observing squatting, would entail looking at the current modes of government through the experience of those who try to resist them: yet not grabbing movements' knowledge, but learning from these perspectives how to know differently.

Drawing on Foucault it will be argued that in order to conduct research that is useful not only for understanding how power relations work, but also for resisting the relation between power and knowledge that is exercised through social research, it is necessary to subvert the rationality and truth formations at stake. In first place this entailed questioning the truth formations that govern our modes of thought and unlearning traditional assumptions on objectivity, and validity of academic research, which are still fixed into the scientific dialectic of object and subject of knowledge. In second place this process led to learning different ways of producing knowledge, and to do so from the perspective of practices of resistance that are engaged in problematising power relations and in uncovering their points of application (Foucault, 1998). Thus, it will be argued that is necessary to use theoretical and epistemological tools that do not attempt to conduct research about movements, but that work alongside movements, learning from the movements' modes of knowing, and using movements' experiences as theoretical and epistemological perspectives. This, not only for avoiding the representation and repression of resistant practices, but also for using research practices as tools of resistance.

\section{What is Critical about Critical Methods?}

Following Marx's eleventh thesis on Feuerbach - "The philosophers have only interpreted the world, in various ways; the point is to change it" (Marx, 1845) - it has been argued that the aim of critical research is to contribute to social change and political transformation. So called 'critical' research methods have attempted to put this thesis into practice. 'Critical ethnography', for instance, has often been addressed as an important method both for researching from within the field of interest, and attempting to contribute to political change. However, the main tools used by critical ethnography are those of 'participant observation'. Throughout this paper both concepts of participation and of observation will be problematised, and it will be argued that the task of critical research is not simply to change the world, but, in first place, to reflect on the how specific ways knowing the world become truth, and, in second place, to explore different possibilities of knowing the world.

The definition of critical ethnography provided by Jim Thomas (1992), referenced in most of the related literature, argues that "critical ethnography is like traditional ethnography with a political aim" (Thomas, 1992, p.11). This definition is highly problematic since traditional ethnographic research did have strong political implication, as it was used as a source of knowledge aimed at understanding colonized cultures and to extend colonisation further (Gough, 2008). The first ethnographic studies addressed the populations, cultures and histories of colonies within the British Empire, but defined themselves as unbiased and impartial account of the actual state of affairs. Affirming that 'critical ethnography is like traditional ethnography with political aims', seems to dismiss the fact that traditional ethnography did entail strong political effects and did serve as a tool for social transformation: namely the governing of colonised and indigenous populations by Western colonial powers whose aim was explicitly to understand in order to change, or to know in order to subject, to control, and to exploit the researched populations.

Linda Tuhiwai Smith (2012) addresses the colonial implications of critical social and 
anthropological research on indigenous communities, which, even when they wave the flag of emancipatory research, still order, code, and objectify indigenous experiences, thereby imposing Western categories and modes of knowing: from her perspective "the word itself, research, is one of the dirtiest words in indigenous world's vocabulary" (Smith, 2012, p.1). However she does not claim that 'research' as such should be abolished; rather, she considers theory and analyses as important tools "to plan, strategise, to take greater control over our resistance" (Smith, 2012, p. 38). Therefore the problem does not lie in research as such, but in the ways 'proper' research and 'true' knowledge are defined by scientific (Western, white, male) standards which dismiss and silence different epistemological possibilities (Denzin et al, 2008).

Thus, it is important to question to what extent so called critical ethnographic practices had a role in effectively challenging and subverting traditional colonial discourses. If colonisation is intended as an ongoing process of grabbing and governing peoples, lives and knowledge formations, both traditional and critical research methods have to be de-colonised, and it is necessary to find new languages, tools, and modes of thought, for decolonizing theoretical apparatuses and epistemological devices (Sandoval, 2000). In order to be effectively 'de-colonised' research should not simply aim at producing tools for 'social transformation', but at becoming reflective on the power effects of the knowledge produced, and at finding different ways of knowing (Holloway, 1998; Shukaitis et al., 2007).

The situated nature of knowledge has also been extensively discussed by feminist epistemologies who made explicit the politics of research and 'science' and questioned the partiality and exclusiveness of truth formations that shape knowledge and thought (Smith 2005, Wray 2002). Feminist standpoint epistemologies challenge mainstream systems of research objectivity and ethics, and questions whose truth, whose knowledge, from what perspective and for whom is research produced (Harding, 1991). These subversive epistemologies have attempted to produce alternative ways of knowing, and experimented with modes of research in which researchers could situate themselves in a position that does not exercise power upon, while supporting the potentialities of the reality researched. From these perspectives the call for objectivity is replaced with an attention of the subjective dimension of the research experience. As most scholars still value rigorous detachment and distance, and the formulation of objective and scientific analyses and results as the main criteria for the production of truth, recurrent criticism of feminist subjective perspectives questions the extent to which these voices reproduce the very discourses that oppress them (Willis, 1977) and to the extent to which voices can claim to hold more truth than others (Hammersley, 2012). But is it possible to go beyond the dialectic between subjective and objective modes of knowledge?

These longstanding disputes have been discuused in the Becker and Gouldner debate, and they revolves around whether it is necessary to speak about or for the social reality one is analysing and which view point should be adopted while conducting research (Becker, 1967; Gouldner, 1968). While Becker (1967) argues, in his article 'Whose side are we on?', that the social scientist should hold the perspective of the oppressed, Gouldner (1968) has argued that this attitude entails the risk of acting as 'zoo-keeping' researcher, who stands on the side of the oppressed but keeps it in a cage, as this modes of research do not provide tools to transform the relations of power that lead to the very oppression. Hence, the effects of so-called the 'zookeeper' attitudes are to provide knowledge to understand, to manage and control the oppressed rather than to address the causes of oppression. In his view, the role of the researcher is not to give meaning to and make sense of the life-world of the oppressed practices, but to analyse and intervene in the causes of oppression.

According to Gouldner (1968), academics must therefore formulate theories that are able 
to locate the various perspectives and actors involved within a broader political historical and cultural context. Despite the relevance of this approach for avoiding the zoo-keeping of the so called 'other', 'vulnerable' or 'oppressed', Gouldner's argument assumes a clear distinction between the subject and object of research, the micro and macro levels, and claims to the maintenance of institutionalized distance between theory and praxis, thus reproducing classical scientific paradigms, and keeping the theorist at the centre of the epistemological practice.

Moreover, posing a clear-cut distinction between the powerful and the powerless, the dominator and the oppressed, silences and dismisses the capacity of non-academics to take action and challenge the power enacted upon them, and to grasp them as key forces within the power relations. Thus, posing oneself in a specific standpoint does not necessarily mean occluding the focus on the macro dynamics at stake. Rather, the vertical geometry and hierarchy between macro and micro can be challenged by looking at how relations of power traverse and resonate within each body (Deleuze \& Guattari, 2004).

\section{The Methods of the Eye: Research about Social Movements}

Translating the above debate more specifically into social movements research methods, Becker's approach could be referred to as a 'methods of the eye', since speaking about/or of the movement entails observing the movement, its demands, strategies, repertoires of action and historical cycles from an external point of view (on this perspectives see among others: McCarthy \& Zald, 1977; Kitschelt, 1986; Kriesi et al., 1992; Giugni et al., 1999; Mcadam et al., 2003). Although these studies have been very important for understanding general patterns and common features of various forms of protest through time and space, they tend to be more popular among academics than in social movements, as they construct macro-theories and find general patterns of cause-and-effects relations that seem to be of little interest for social movements themselves (Juris, 2013). Through the use of qualitative methods such as 'participant observation', many social movement scholars position themselves as theorists whose roles are still limited at using movements as objects of observation, or as a case to test hypothesis. The researcher becomes an external observer who accesses the movement, grabs its knowledge and often leaves the scene without any substantial contribution (Graeber, 2009). Thus, too often social movements studies are aimed at describing the movement, producing general theories about movements, and make little effort to reflect on the the multiple and controversial ethical implications of these practices. Although researchers are often sympathetic or supporters of movements struggles, these modes of research produce representations, discourses and truthformations about movements that more often than not play into framing, coding and thereby confining the practices studied.

The power/knowledge implications go beyond data collection and analysis, and extend to the dissemination of the data. Indeed, what I would refer to as 'the researchers of the eye' tend to claim the necessity of translating the research results to make them understandable for the movement audience (Chatterton, 2008). However, it could be argued that if academic work needs to be translated, this is frequently more due to the academic's rather than the activist's limited scope of understanding. When translation is needed, this is not because of a supposed incapacity of activists to understand research results, but mainly because academic language tends to close itself within the fortress of discipline-specific jargon. The writing task should aim at producing a different language rather than translating 'scientific' research, and at reisisting the way the politics of scientific truth pass through academic discourse and shape the possibilities of knowing. 


\section{The Method of the Voice: Research for Social Movements}

An alternative often proposed by critical researchers, instead to positioning oneself as an external observer of ongoing struggles, is to conduct research from within, to help movements elaborate their struggle (Croteau et al., 2005). Researchers often take the role of speaking for, or in the name of, a given movement. Such research aims at representing movements to give voice to the struggle, to bring subjugated voices to the outside. The political goal is to produce knowledge for the purpose of empowering rather than controlling the oppressed and marginalized (Brown \& Strega, 2005).

Feminist critiques, for instance, often argue that taking the perspective of those at the bottom of the social hierarchy, of the oppressed and of the marginalised, is the only way to shed light on the dynamics of power at stake (Harding \& Hintikka, 2003; Lather, 2007). But is it possible that these very efforts to liberate perpetuate the relations of dominance at stake (Lather \& Lather, 1991, p.16)? What if the so called oppressed and marginalised already have the capacity to alter the relations of oppression and do not need to be empowered by the researcher (Juris, 2008)? These questions are intricately interconnected, and highlight important epistemological, ethical and philosophical dilemmas. Methods such as Action Research, or Participatory Action Research (PAR) place the focus on participation, in order to reduce power acted upon the reality studied (Selener, 1997). There are multiple paradigms and tools subsumed under the umbrella term PAR, but the common particularity lies in the shifting role and definition of the researcher, who becomes a facilitator, rather than an 'expert', and the process of research aims at giving power to the power-less. PAR differs from observational methods in that it does not attempt to reduce the complexity of reality and experience to mere representation, nor at making truth claims from an external perspective. Rather the political task of PAR practitioners is to let the 'researched' participate in the definition of the research focus, questions and objectives (Kindon et al., 2007). Such research practices aim at a bottom-up discovery of local, situated knowledges with methods based on inclusion rather than extraction, on participation rather than appropriation. These methods, have often combined feminist criticism with knowledge production, have put into question the traditional hierarchies and divisions between theory and practice and led to the acceptance of new modes of research within diverse academic spheres.

Despite their importance in paving the way for reflexive research practices, many of the research projects using these methods aim at including the power-less and voice-less in a participatory process of empowerment. By claiming to give power to the power-less, and at discovering the authenticity and truth of silenced voices, these approaches still use a language and a discourse that tends to position the researcher as the liberator or the emancipatory force of oppressed subjects. As discussed above, methods that call for the inclusion of the powerless, of the subjugated and of the vulnerable tend to reduce the complexity of power relations to a clearcut distinctions between the powerful and the powerless, the power holder and the subjected. Moreover, although participatory methods tend to distance themselves from speaking 'on behalf of', the aim remains focussed on bringing expertise and tools and researching for, thereby failing to break with the hierarchy between activist and scholar, theory and praxis.

Paradoxically, attempts to represent resistant experiences and to raise voices imply that the researcher rarely joins the struggles (Kitchin \& Hubbard, 1999, p.196) and, willingly or not, exercises power and acts upon their modes of knowledges and research practices. Following Cohen (1985), Kothari (2001) points out that the dynamic of participation functions as yet another form of 'tyranny' (Cooke, 2001) where the participants are fed the illusion of having a voice in decision-making processes that will eventually harm them or serve for their control. 
In other words participatory practices have been criticised for exercising subtle methods whose effect is to tame the possibility of resistance, and to conceal relations of power/knowledge and outside agendas (Kindon et al., 2007).

To summarise, these research techniques involve an approach that assumes a clear-cut distinction between knowledge and practice, where the activist is the subject and object of research, and the academic its eye or voice to the outside: this implies that the researcher is the 'expert' on other's struggle, and, as such, remains the central source of knowledge (Chatterton et al., 2010).

Thus, the method of the 'eye' and 'voice' both entail a form of representation: in the former the researcher is an external observer who analyses the inside world of the movement and, although the knowledge produced is partial, it often claims that it is universal. While the force of social movements is often expressed by their intensity and variety (Chesters \& Welsh, 2005) attempting at a general representation fixes and represses their multiplicity and complexity. The second approach entails researchers electing themselves as political representative of movements, representing movements' voices, speaking on behalf of, or as an emancipatory voice of movements. Researchers that position themselves as an empowering subject of the voice-less, reduce social movements to marginal and vulnerable populations, and classify political activists as passive subjects, unable to know, to speak and act for themselves. Therefore both approaches entail a form of repression: the former by enabling representations that often produces specific discourses about the practices, thus coding and controlling the struggle; the latter, by subjectifying the struggle, speaking on behalf of, and appropriating activists' voices with the presumption of giving them a voice.

In the collection of essays titled 'Rhyming Hope and History' (2003) academics conducting social movements research discuss their role as intellectuals, and their relation to activism. The questions raised relate to how academics, through the production of their knowledge, can support social movements. The authors call for closer connections and collaborations between activists and academics, and for collaborative practices where academics can learn from social movements, As Aldon Morris (2002) claimed at the "Hope and History" conference: "Maybe we could bring social movement theorists into the real world of social movements - to struggle and experiment with different tactics and strategies, to collect data on strategies, to analyse them, and think it all through [while] out in the field, in the actual heat of the struggle. Maybe the activists should say [to the theorists], 'Come out here and let's see what we can learn together'.

Indeed contemporary social movements and resistant groups articulate, produce and disseminate critical knowledges in a way that does not need, and actually does not welcome, the intervention of external observers, experts or intellectuals willing to represent, code, or organise their practices. Rather, academics can learn from these different modes of knowing, and their research practices can serve as an additional tool, within a multitude of already existing tools. In order to stop observing, representing or repressing, researchers need to learn from movements experiences, and research need to be inscribed within the multiplicity of practices, of methods and epistemologies of the movement itself.

\section{The Method of the Body: Research along Movements}

To the Gramscian distinction between the traditional and organic intellectual (Gramsci 2010), Foucault adds the concept of the 'specific intellectual' (Foucault 1980), who does not make universal claims but works in specific contexts and on particular practices: "The intellectual's role is no longer to place herself somewhat ahead and to the side in order to express the stifled 
truth of the collectivity; theory is an activity conducted alongside those who struggle for power and not their illumination" (Foucault \& Deleuze, 1977). Thus, the role of the researcher is not one of the public intellectual who raises the voices of the movement to a virtual 'outside'. Instead, the 'specific intellectual' will work in collaboration with movements, and will have a specific role in singular struggles. Here the position of researchers is immanent rather than external to the struggle, yet alongside the struggle rather than at its centre. The body and voice of the researcher relays the multiplicity of bodies and voices, and the sources of knowledge are collective research practices rather than an individualised researcher.

In order to avoid claim to universal representation, the role of research becomes one of bridging singular practices, isolating elements, understanding how the relations of power resonate traversing these elements and developing epistemological devices that give attention to the details and raptures rather than to progress and continuities, and to points of encounter between different elements rather than teleological views (Mahon, 1992; Tamboukou, 1999; Deleuze, 2006;). This perspective implies that, instead of looking for an universal subject that embodies resistance, or searching for a general model, it becomes possible to individuate singular and situated practices that operate within complex relations of power, and that counter their capillary effects through tactical use and through a reversal of the relations in which they are embedded.

The aim of these research practices becomes one of producing tools that inscribe themselves within movement's struggles, to produce forms of knowledge that are neither extractive nor inclusive but instead collaborative (Brown \& Strega, 2005; Shukaitis et al., 2007; Juris, 2013) and multiply the potential for collective political action, rather than for representation and repression. Following the feminist and queer approaches, this method can be defined as the 'method of the body', as research here is not separated from embodied experience, and theory is not situated on a different level from the affects and desires involved in the process of research. Here the body of the researcher and the one of the activist can coexist in a common space of theory and praxis, and become the starting point of epistemological practices.

From the perspectives of these critiques, Marx's thesis could been reformulated by arguing that in order to understand the world in first place, it is necessary to become directly involved in the struggles to change it. Only then it becomes possible to stop observing, to combine theory and praxis, and research becomes not only a gaze but also a mode of resistance.

This approach is mainly used by post-colonial, queer and activist researchers engaged in autonomous and alter-global politics (Escobar, 1992; Brown and Strega, 2005; Shukaitis et al., 2007; Denzin, 2008; Graeber, 2009; Browne and Nash, 2010; Smith, 2012; Juris, 2013). Here the main actors are not conventional movements that seek to gain power within traditional institutions, but ways of life and political organisation that, as with squatting, aim to unsettle and transform relations of power by opening up the possibility of different relations to emerge. With these research projects activism "becomes not simply an object of analysis but a politically engaged mode of research, which not only generates relevant knowledges, but also potentially constitutes a form of activism itself "(Juris, 2013, p. 9). The research aim is to contribute to rather than to objectify or subjectify the struggles, by considering movements as active producers of knowledge, and, from here, learning different modes of knowing.

An important contribution that aimed at going beyond classical scientific paradigms and at breaking the dialectic of objective/subjective research, can be found is Dorothy Smith (2005) 'institutional ethnography': namely, a method of inquiry for mapping the social relations mediated by texts that organize institutions. Dorothy Smith (2005) argues that the aim of critical sociology is not to use social groups and processes to test hypothesis or explicate theories, but to uncover how relations of power have an effect on the local sites of action, from an embodied, 
situated standpoint in the everyday world (Smith, 2005). This rejects the productions of objective accounts, not in favour of subjective epistemology, but of reflexive modes of knowledge, not about people, but for people, where 'for' addresses a reflexive knowledge of the people (Scholl, 2012).

Similarly, post-colonial practices and research by indigenous populations have challenged the way the colonised are labelled as powerless communities 'at the margins' and considered as 'objects', rather than 'authors' of research, and developed methods that allowed to conduct research that aims nor at objectifying nor at empowering, but one that is done by experiencing indigenous conditions and, from here, problematising the relations of power that traverse these conditions (Smith, 2002; Brown \& Strega, 2005) Throughout her work Linda Tuhiwai Smith searches for methods and conceptual tools that would decolonise research practices, namely projects locally conducted by members of the populations and where the research process has priority over the research outcomes. The aim indeed is not to produce data clusters and categories, but to contribute to processes of collective reflection, and to create relays between already existing knowledges. In this context indigenous groups are authors and conductors of inquiries that bridge local and embodied experiences with the global flows of power (Smith, 2002).

To summarise, while traditional research methods place the researchers on the outside, seeking 'objective' and 'scientific' analyses about a researched population, queer, post-colonial and activist approaches value embodied experience and reflexive accounts (Motta, 2009). These epistemological practices offer alternatives to the assumptions that theory must be derived from a process of abstraction, detached from everyday struggles. Rather, they considers movements as capable of producing theory through praxis. From queer, postcolonial and activists perspectives the aim is to unlearn traditional methods and to find different tools that contribute not only to the theoretical debate, but to experiment with different modes of thought. Rather than adhering to the binary opposition of speaking about, or for a movement, these radical approaches aim at researching alongside movements, therefore substituting observations and interviews with collective research practices and reflections (Henninger \& Negri, 2005). Here the entire body of the researcher becomes entangled with the struggle, not just its eye or voice: thus the researcher does not merely observe or participate in the life world of the movement, but movements experiences become epistemological perspectives.

As discussed above, from a classical scientific academic perspective the 'methods of the body' can be criticised for lack of objectivity, for an exaggerated bias due to the embodiment of affects and experience, and for placing too much efforts on the micro, without relevant understanding of the macro dynamics of power. However, once more, concepts such as 'objectivity' and 'subjectivity' are directly from the classical epistemological tradition, the politics and effects of which, need to be challenged (Smith, 2012) by going beyond the dialectics of macro and micro, particular and universal, empirical and abstract, and theory and praxis (Baugh, 1992). Here the viewpoint at stake is not related to subjectivity versus objectivity, but it seeks to problematise what sets of conditions produce specific relations, practices and discursive formations where life is experienced.

Deleuze and Guattari (2004) name haecceity as a method for the analysing an event in its multiplicity. Haecceity refers to the 'here and now' and assumes that the foreground and the background resonate within each other, as they are part of a multiple and complex assemblage that shapes the world ${ }^{1}$. Therefore, embodied practices of research, do not fail to understand the

1 As in Deleuze and Guattari's passage on a poem by Federico Garcia Lorca (Llanto por Ignacio Sánchez Mejías): “It is the entire assemblage in its individuated aggregate that is a haecceity; it is this assemblage that is defined by a longitude 
relation between macro and micro, as relations of power are understood to circulate transversally and not vertically, and to resonate in each body and event. By engaging with these perspectives and methods, going beyond the distinctions between object and subject of knowledge and between theory and praxis, it becomes possible to resist and erode the truth formations of academic research.

\section{The Criminalisation of Squatting in the Netherlands}

Squatting, in literal terms, means to occupy a space without the authorisation of the owner: however, squatting is not just about trespassing, as squatting functions by making creative use of the places occupied, transforming the relations of power that traverse these spaces. The Dutch word for squatting, kraken, refers to the very action of break opening a private space to which access is prohibited. As a practice, kraken, is a tool that can be used in a variety of ways: for solving a housing problem, for creating sites of urban struggle, or for opening spaces where a variety of practices of resistance can take place: from organisation of political action to experimenting with different modes of life, politics and ethics (Sqek, 2012).

In the Netherlands the practice of squatting has been tolerated and regulated since 1914, when the right to housing was considered to have priority over the right to property, therefore allowing the occupation of unused spaces to satisfy housing needs (Uitermark, 2004). In 2010, after many decades of so called 'regulated tolerance', a new law turned the occupation of unused properties into a criminal act. The law that criminalised squatting not only addresses the action of trespassing, but it specifically addresses the social and political movements that use squatting as a tool of resistance.

Despite the relevance of the criminalisation of collective practices of resistance for both criminology and social movements studies, neither fields have given much attention to these processes. Indeed social movements studies that take the perspective of criminalisation mainly focus on policing protests (Della Porta \& Reiter, 1998; Fernandez, 2008; Lovell, 2009). However, as Alberto Melucci (1989) has pointed out, social movements are not only expression of protest. Protest is an oppositional episode that does not shed light on the creativity of movements, on the everyday practices of resistance that shape and transform the relations of power that movements resist. Movements do not stand outside power, as pure opposition, but instead, power and resistance form assemblages of relations that mutually compose each other. Squatters movements, as with many other resistant groups, enact modes of politics that go beyond protest and opposition. They constitute hubs for the production of different social and urban spaces, of critical knowledges, and of resistant modes of life (Adilkno, 1994; Uitermark, 2004; Hodkinson \& Chatterton, 2006; Martinez \& López 2012).

Just as squatting does not merely express opposition, the law that criminalised it is does not only entail repression: it is a complex process that involves a multiplicity of actors, techniques, and rationalities, on multiple levels. Here, other less visible, more subtle strategies are at play, which do not simply repress, but normalise, tame and conduct resistant practices and latitude, by speeds and affects, independently of forms and subjects, which belong to another plane. It is the wolf itself, and the horse, and the child, that cease to be subjects to become events, in assemblages that are inseparable from an hour, a season, an atmosphere, an air, a life. The street enters into composition with the horse, just as the dying rat enters into composition with the air, and the beast and the full moon enter into composition with each other [...] Climate, wind, season, hour are not of another nature than the things, animals, or people that populate them, follow them, sleep and awaken within them. [...] We are all five o'clock in the evening, or another hour, or rather two hours simultaneously...» (Deleuze \& Guattari, 2004, p.262). 
and discourses. Moreover the process of criminalisation is strongly influenced and shaped by squatters' attempts to counter criminalisation, whether they take place in the streets, in court, or as the 'hidden transcripts' discussed by James Scott (1990). These resistant practices constituted a strong capacity for challenging how the process of criminalisation works, and for subverting its effects on criminalised movements (Dadusc \& Dee, forthcoming). Hence, in this context, criminalisation is not to be understood as a top-down process, where those affected are passive subjects with no power of action: rather, forces of criminalisation and practices of resistance constitute a complex game of power, an assemblage of forces and relations that mutually influence each other. Therefore, the relations of power entailed in criminalisation are neither fixed nor static, but instead they are in continuous transformation, a transformation that comes from the possibility, and from the action of, resistance. This implies that the actors involved in resisting criminalisation entail a reflexivity, experience, analytical capacities, and modes of knowledge of the relations in which they are embedded that goes far beyond what can be grasped by the academic gaze of an outsider.

\section{Learning from Resistance}

The practices of resistance that take place through squatting are not only configured as an antagonistic opposition, nor are they marginal, oppressed, or 'other' to power. Rather, they traverse the relations in which they are embedded and problematise their effects. The people and collectives that are engaged in squatting actively bring attention to everyday struggles and confront mechanisms of power that exploit, conduct and produce specific truth formations. These resistant forces are not external but immanent to relations of power, and aim at subverting the effects of power by opening up different fields and possibilities for action and for thought.

Thus, these very struggles reveal points of rapture and contention which can unmask how power relations work (Simons, 1995) . Resistant practices by transforming, but also in unmasking hidden, "normalised", or taken-for-granted techniques of power and regimes of truth function as monsters, rather than models, of different modes of knowledges. Hence, the gaze of resistances to specific techniques of power enable an understanding of the sites and modes of operations, mechanisms, points of application and rationalities of power (Foucault, 1982). As Cadman (2010) has noted, practices of resistance (such as squatting) operate as 'transactional realities', as points of fracture between the smooth continuity of the work of power, and the possibility of different modes of doing things, of becoming, and of knowing. Thus, by learning from the perspectives of those practices and events that constitute difference and that challenge the 'normal ordering of things', it is possible to unmask and question those effects of power that shape our lives and to problematise how one should constitute oneself as a political, moral and desiring subject in the Western societies of our time (Foucault, 1990).

On the one hand understanding the mentalities and techniques of the criminalisation of squatting by aiming at resisting them, gives insight into how urban machine functions, with its practices of gentrification, dispossessions, housing policies, real estate speculation, and the disciplining and normalisation of what differs from the supposed 'normality'. On the other hand, using the methods of the body, brings to the surface dispositifs of power that not only work on the field of politics, but that also operate on the level of ethics. Indeed criminalisation has effects on affects, desires, and bodily experiences that can only be grasped by experiencing and resisting criminalisation through one's own body.

Thus, the academic's role is not the one of representing, but one of inserting oneself into these fields, of becoming part of resistant practices with her own body, thereby resisting the 
effects of power that pass through academic modes of knowledge. Within this context the traditional boundaries between academic and activist are blurred, because research becomes a practice of resistance in itself, a relay between radical theory and praxis and, as such, an additional tool for the existing struggles.

\section{Conclusion}

Drawing on Foucault's conceptualisation of power and resistance this paper explored how different research methods for social movements have specific power effects on the reality researched and on the struggles taking place. In particular it has been argued that, in order to understand how relations of power work, it in important to use the gaze of practices of resistance that question and subvert the very relations of power one is analysing. It has also been questioned how the role and the standpoint of the researcher shape and affect the knowledge that is produced. By drawing on multiple research traditions and perspectives, it has been argued that academics have been engaging in attempt not only to understand the world, but also to change it. However, dislocating and acknowledging researchers' standpoints is not enough for challenging the relations of power entailed in the production of knowledge, as research methods frequently tend to reproduce the positivist dialectic between object and subject of knowledge, and hierarchical relations between theory and praxis, researcher and researched, academics and activists. Although it might be impossible to entirely step out of the norms that govern academic modes of thought, it is important to problematise the effects exercised by academic truth formations, and to reflect on how to engage in modes of research that are not only oriented toward universities and governments, but that in themselves function as practices of resistance.

By drawing on the experience of doing research on the criminalisation of squatting in the Netherlands, the paper has explored research practices that have been experimenting with alternative modes of knowledge production, and that attempted to challenge the relations of power entailed in social research. In particular, post-colonial, queer and activists approaches were addressed as techniques that enable research itself to be employed as a tool for resistance Indeed, these epistemologies neither attempt to represent a social world nor to empower social movements. Instead, the aim becomes to learn from movements' modes of knowledge, and to do research by embodying and experiencing practices of resistance. Here movements become active forces in the production of knowledge, and constitute an epistemological perspective. 


\section{References}

ADILKNO. (1994). Cracking the movement: Squatting beyond the media. Brooklyn, NY: Autonomedia.

Baugh, B., (1992). Transcendental empiricism: Deleuze's response to Hegel. Man and World, 25, 133-148.

Becker, H.S. (1967). Whose Side Are We On?. Social Problems, 14, 239-247.

Brown, L. A. \& Strega, S., (2005). Research As Resistance: Critical, Indigenous, and Anti-Oppressive Approaches. Canadian Scholars' Press.

Browne, K., \& Nash, C. (2010). Queer methods and methodologies: Intersecting queer theories and social science research. Ashgate Publishing.

Cadman, L. (2010). How (not) to be governed: Foucault, critique, and the political. Environment and Planning D: Society and Space, 28, 539-556.

Chatterton, P. (2008). Demand the Possible: Journeys in Changing our World as a Public Activist-Scholar. Antipode, 40, 421-427.

Chatterton, P., Hodkinson, S., \& Pickerill, J. (2010). Beyond scholar activism: making strategic interventions inside and outside the neoliberal university. ACME, 245-75.

Chesters, G. \& Welsh, I. (2005). Complexity and Social Movement(s). Theory, Culture \& Society, 22, $87-211$.

Cohen, S. (1985). Visions of Social Control: Crime, Punishment and Classification, Wiley.

Cooke, B. (2001). Participation: the new tyranny? London; New York: Zed Books.

Crampton, J. \& Elden, S. (2007). Space, Knowledge and Power: Foucault and Geography. Ashgate Publishing Limited.

Croteau, D., Hoynes, W. \& Ryan, C. (2005). Rhyming hope and bistory: activists, academics, and social movement scholarship. Minneapolis: University of Minnesota Press.

Dadusc, D., and Dee, E. T. C. (Forthcoming). The criminalisation of squatting: Discourses, moral panics and resistances in the Netherlands, England and Wales.

Deleuze, G. (2006). Nietzsche and Philosophy. Bloomsbury Academic.

Deleuze, G. \& Guattari, F. (2004). A thousand plateaus: capitalism and schizophrenia. Continuum International Publishing Group.

Deleuze, G. \& Parnet, C. (1987). Dialogues. New York: Columbia University Press.

Della Porta, D. \& Reiter, H. (1998). Policing Protest: The
Control of Mass Demonstrations in Western Democracies. Minnesota: University of Minnesota Press.

Denzin, N.K., Lincoln, Y.S. \& Smith, L.T. (2008). Handbook of critical and indigenous methodologies. Los Angeles: Sage.

Duivenvoorden, E. (2000). Een voet tussen de deur: geschiedenis van de kraakbewegning (1964-1999). De Arbeiderspers.

Escobar, A. \& College, S. (1992). Anthropology and the study of social movements. Critique of Anthropology, 12, 395-432.

Fernandez, L.A. (2008). Policing dissent: social control and the anti-globalization movement. Rutgers University Press.

Foucault, M. (1980). Power/knowledge: Selected interviews and other writings, 1972-1977. Random House Digital, Inc.

Foucault, M. (1982). The Subject and Power. Critical Inquiry, 8, 777-795.

Foucault, M. (1990). The History of Sexuality, Vol. 1: An Introduction. Vintage.

Foucault, M. (1998). Aesthetics, method, and epistemology. New York: New Press.

Foucault, M. (2009). Security, Territory, Population: Lectures at the College de France 1977-1978. Picador.

Foucault, M. \& Deleuze, G. (1977). Intellectuals and power. Language, counter-memory, practice, 205-17.

Giugni, M., McAdam, D. \& Tilly, C. (1999). How social movements matter. University of Minnesota Press.

Gouldner, A.W. (1968). The sociologist as partisan: Sociology and the welfare state. The American Sociologist, 3, 103-116.

Graeber, D. (2009). Direct Action: An Ethnography. AK Press.

Gramsci, A. (2010). Prison notebooks: Volume 1. New York: Columbia University Press.

Hammersley, M. (2012). Taking Sides in Social Research: Essays on Partisanship and Bias. Routledge.

Harding, S. G. (1991). Whose Science? Whose Knowledge?: Thinking from Women's Lives. Cornell University Press.

Harding, S. G. \& Hintikka, M. B. (2003). Discovering reality: Feminist perspectives on epistemology, metaphysics, methodology, and philosophy of science. Springer.

Henninger, M. \& Negri, A. (2005). From Sociological to Ontological Inquiry: An Interview with Antonio Negri. Italian Culture, 153-166.

Hodkinson, S. \& Chatterton, P. (2006). Autonomy in the city? City, 10, 305-315. 
Holloway, J. (1998). Zapatista!: reinventing revolution in Mexico. London; Sterling, VA: Pluto Press.

Juris, J. S. (2008). Networking futures: The movements against corporate globalization. Duke University Press.

Juris, J. S. \& Khasnabish, A. (2013). Insurgent encounters: transnational activism, ethnography, and the political. Duke University Press.

Kindon, S. L., Pain, R. \& Kesby, M. (2007). Participatory Action Research Approaches and Methods: Connecting People, Participation and Place. Routledge.

Kitchin, R.M. \& Hubbard, P.J. (1999). Research, action and 'critical' geographies. Area, 31, 195-198.

Kitschelt, H.P. (1986). Political Opportunity Structures and Political Protest: Anti-Nuclear Movements in Four Democracies. British Journal of Political Science, 16, 57-85.

Kothari, U. (2001). Participatory Development: Power, Knowledge and Social Control. In Kothari, U. \& Cooke, B, (Eds), Participation: the New Tyranny?. London: Zed Books; 2001

Kriesi, H. et al. (1992). New social movements and political opportunities in Western Europe. European Journal of Political Research, 22, 219-244.

Lather, P. \& Lather, P.A. (1991). Getting smart: Feminist research and pedagogy with/in the postmodern. New York: Routledge.

Lather, P. A. (2007). Getting lost. State University of New York Press.

Lovell, J. S. (2009). Crimes of Dissent: Civil Disobedience, Criminal Justice, and the Politics of Conscience. NYU Press.

Mackenzie, I. \& Porter, R. (2011). Dramatization as method in political theory. Contemporary Political Theory, 10, 482-501.

Mahon, M. (1992). Foucault's Nietzschean genealogy: Truth, power, and the subject, SUNY Press.

Martínez, M. (2007). The Squatters' Movement: Urban Counter-Culture and AlterGlobalization Dynamics. South European Society and Politics, 12, 379-398.

Marx, K. (1845). Theses on Feuerbach. The MarxEngels Reader, 2, 143-45.

Mcadam, D., Tarrow, S., \& Tilly, C. (2003). Dynamics of Contention. Social Movement Studies, 2, 99-102.

McCarthy, J. D. \& Zald, M. N. (1977). Resource Mobilization and Social Movements: A Partial Theory. The American Journal of Sociology.

Melucci, A. (1989). Nomads of the present: social movements and individual needs in contemporary society. London: Hutchinson Radius.
Morris, A. (2002). Remarks at the "Hope and History" conference, Boston College, June 13. Quoted in Croteau, D., Hoynes, W. \& Ryan, C. (2005). Rhyming hope and history: activists, academics, and social movement scholarship, Minneapolis: University of Minnesota Press., p xviii

Motta, S.C. (2009). Old tools and new movements in Latin America: political science as gatekeeper or intellectual illuminator? Latin American Politics and Society, 51, 31-56.

Pickerill, J. \& Chatterton, P. (2006). Notes towards autonomous geographies: creation, resistance and self-management as survival tactics. Progress in Human Geography, 30, 730-746.

Sandoval, C. (2000). Methodology of the oppressed, Minneapolis, MN: University of Minnesota Press.

Scott, J. (1992). Domination and the Arts of Resistance: Hidden Transcripts, Yale University Press.

Selener, D. (1997). Participatory action research and social change. The Cornell Participatory Action Research Network, Cornell University.

Shukaitis, S., Graeber, D., \& Biddle, E.. (2007). Constituent imagination: Militant investigations collective theorization. Oakland, CA: AK Press.

Simons, J. (1995). Foucault and the political, Routledge.

Smith, D. E. (2005). Institutional Ethnography: A Sociology for People. Rowman Altamira.

Smith, G. W. (1990). Political Activist as Ethnographer. Social Problems, 37, 629-648.

Smith, L.T. (2012). Decolonizing Methodologies. London: Zed Books.

Sqek (2012). Squatting in Europe Radical Spaces, Urban Struggles., Minor Compositions.

Tamboukou, M. (1999). Writing Genealogies: an exploration of Foucault's strategies for doing research. Discourse: Studies in the Cultural Politics of Education, 20, 201-217.

Thomas, J. (1992). Doing Critical Ethnography, SAGE.

Uitermark, J. (2004). Framing urban injustices: the case of the Amsterdam squatter movement. Space and Polity, 8, 227-244.

Willis, P.E. (1977). Learning to labour: how working class kids get working class jobs. New York: Columbia University Press.

Wray, K.B. (2002). Knowledge and Inquiry: Readings in Epistemology. Broadview Press. 